\title{
Smokers' sexual behavior and their satisfaction with family life
}

Eiji Yamamura

ISSN: 2031-4892

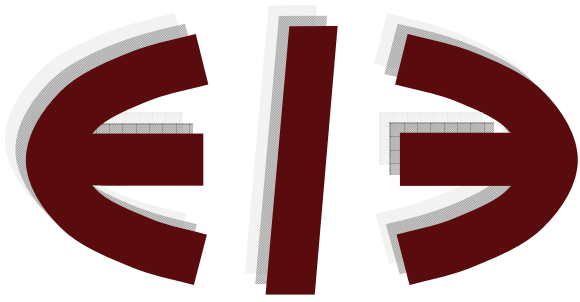

EERI

Economics and Econometrics Research Institute Avenue de Beaulieu 1160 Brussels

Belgium

Tel: +3222988491

Fax: +322 2988490

www.eeri.eu 
Smokers' sexual behavior and their satisfaction with family life Eiji Yamamura

Department of Economics, Seinan Gakuin University, 6-2-92 Sawaraku Nishijin, Fukuoka 814-8511, Japan

E-mail: yamaei@seinan-gu.ac.jp

Tel: 81-(0)92-823-4543

Fax: 81-(0)92-823-2506 


\begin{abstract}
It has been recently recognized that there is difference of preference between smokers and non-smokers. That is, smokers tend to be more impatient and prefer immediate benefits compared with non-smokers. If people follow their primitive instincts they will engage in sexual behavior. Hence, impatient people are more likely to have sex because it is difficult for them to control their instincts. However, for married people, having sex with a spouse is considered to be an investment in family life to ensure a good marital relationship. Therefore, sex with a spouse is considered to result in a long-term benefit, rather than an immediate benefit. This paper used individual-level data from Japan to investigate how sexual behavior differs between smokers and non-smokers. After controlling for various individual characteristics, the important findings are as follows. (1) Frequency of sex is positively associated with family satisfaction; (2) unmarried smokers are more likely to have sex than unmarried non-smokers; and (3) married smokers are less likely to have sex than married non-smokers. These findings regarding smokers' sexual behavior are congruent with the characteristics of smokers suggested in existing literature.
\end{abstract}

JEL classification: D30; D63; H29; Z13

Keywords: Smoker; Time preference; Sexual behavior; Satisfaction. 


\section{Introduction}

Improving unhealthy lifestyles is an important issue in modern society. It is well known that a person's health status is influenced by whether they smoke or not. Furthermore, smoking around other people results in them being exposed to passive smoking. Hence, smoking can be considered a negative externality. Further, smoking behavior is thought to provide useful information regarding unobservable characteristics of smokers. In the field of social science, smokers are observed to be more impatient than non-smokers and are more present-oriented (e.g., Sato and Ohkusha 2003; Khwaja et al. 2006a, b; Ida and Goto 2009a; 2009b; Harrison et al. 2010). In other words, smokers have higher individual discount rates than non-smokers-the current benefit from smoking outweighs the future cost caused by smoking such as a declining health status. The fact that smoking behavior reflects an individual's characteristics is useful to analyze how myopic people behave in various situations. Various existing empirical works have investigated how smoking is associated with economic outcomes such as wage rate, use of seatbelts and experience of injury (e.g., Hersch and Visvusi 1990; Hersch 1996; Levine et al., 1997; Viscusi and Hersch 2001). ${ }^{1}$ Smokers are observed to be less likely to avert risk (e.g., Khwaja et al. 2006a; Anderson and Mellor 2008; Ida and Goto 2009a; 2009b). ${ }^{2}$

Apart from passive smoking, there seems to be a further possibility that myopic smokers' behavior influences smokers' relationships with surrounding people such as family members. It has been found that happiness caused by marriage declines as the marriage progresses (Lucas et al. 2003; Stutzer and Frey 2006). However, marriage continues to make spouses happy if intimate associations between the husband and wife continue. During their marital life, rational married couples have an incentive to invest in the asset they share. Informal insurance within a marital home, such as mutual aid, is beneficial when couples encounter unforeseen hardship or become elderly and require assistance. These investments are, however, significantly less valuable in the case of divorce and so can be called "marital specific" (Beckerr 1974, p. 338). Accordingly, the reciprocal relationship formed by the investment contributes to risk coping or leads

\footnotetext{
1 Alcohol is also considered an addictive good. Drinking behavior has been observed to increase the likelihood of risky sexual behavior and pregnancy (Sen 2002; 2003).

2 In contrast, there are also studies that found smokers not to be risk takers (Sato and Ohkusa 2003; Harrion et al., 2010). Hence, findings and arguments regarding smokers' preferences for risk vary.
} 
to a long-term benefit.

The "marital specific" investment can be interpreted in various ways. Having sex can be regarded as an important investment to maintain a good relationship with one's spouse. Little sex or lack of having an affair leads to a loveless marriage, reducing the long-term benefit of family life.

This paper is the first to attempt to consider how the characteristics of smokers are associated with the frequency of engaging in sex. A couple's sex life influences their marital satisfaction and therefore affects divorce rates (Fan and Lui 2004). The relationship between a husband and wife is thought to influence fertility rates because intimate relations between them increase the frequency of sexual intercourse. ${ }^{3}$ It is worthwhile to establish whether the preferences of smokers are related to the condition of their family life after marriage. Further, the family conditions of those with preschool children seem to influence human capital accumulation and therefore socio-economic status in adulthood (Francesconi 2008). Knowledge of whether a potential spouse is a smoker or not provides useful information in the marriage market as it reduces information asymmetry between those looking for a spouse. This is because a smoker's preference is possibly associated with their efforts to maintain an intimate relationship with their spouse.

The aim of this research is to investigate how smokers' sexual behavior is different from non-smokers based on individual-level data from the Japanese General Social Survey (JGSS). The major findings of this study are: (1) frequent sex makes married people satisfied with family life, whereas frequent sex does not make unmarried people satisfied with family life and (2) smokers are more inclined to have sex when they are unmarried whereas they are less inclined to have sex once married. These results are not influenced by the likelihood that the spouse is a smoker.

The remainder of this article is organized as follows. Section 2 presents the testable hypotheses. Section 3 describes the data and empirical method used. In Section 4, the estimation results and their interpretation are discussed. The final section offers some conclusions and resulting policy implications.

\section{Hypotheses}

3 There is a positive relationship between fertility rates and the rate of sexual intercourse based on cross-country data (Genda 2010). 
Participation in community activities is considered to be an investment in social capital, which in turns generates benefits for community life (e.g., Putnam 1993; 2000; Glaeser et al. 2002). Investment in family, by having sex, can be considered in a similar way. Having sex can be regarded as signaling love to one's spouse (Mialon 2012). Expressing togetherness and altruism via sex contributes to maintaining an intimate relationship with one's spouse. Hence, having sex can be regarded as an investment in "family capital" by producing a benefit to the marital couple. In contrast, sexual behavior is simply regarded as a consumption good for unmarried people. The marginal utility of having sex with a partner is greater when they first begin having sex together. Furthermore, having sex increases one's happiness (Blanchflower and Oswald 2004). However, according to the law of diminishing marginal utility, the marginal utility of having sex decreases as the frequency (with the same partner) increases. In contrast, having sex leads to an increase in the long-term utility as one gets to enjoy a pleasant family life, although the direct marginal utility from having sex is small. That is, having sex is considered to depend not only on sexual instinct but also on rational calculations for a future benefit. The behavior of myopic people is often based on sexual instinct rather than calculation. Accordingly, people are less likely to invest in "family capital" if they are myopic. On the assumption that smokers are more impatient and more present-oriented, I propose the following hypothesis.

Hypothesis 1:

Smokers are less likely to have sex with their spouse.

In contrast, the marginal utility of having sex is greater if the incidence of sex with the same partner is small. Generally, the accumulated total number of times a person has sex with his or her spouse after marriage is greater than with a boyfriend or girlfriend when one is unmarried. Having sex with a girlfriend or boyfriend is considered to directly increase one's current utility rather than as an investment in a long-term relationship. Thus, a myopic smoker obtains a greater utility from having sex with a girlfriend or boyfriend than an unmarried non-smoker. Accordingly, I raise hypothesis 2.

Hypothesis 2:

Smokers are more likely to have sex when they are unmarried.

\section{Data and Methods}




\subsection{Data}

In this research, I used JGSS data, which was purposefully designed as a counterpart to the GSS (General Social Surveys) from the United States of America. Blanchflower and Oswald (2004) used GSS to investigate how sexual behavior is associated with an individual's happiness. Hence, the results of the research in this paper are comparable to Blanchflower and Oswald's (2004). Further, Genda (2010) also used the same JGSS data to ascertain the determinants of sexual behavior. However, he did not examine how smokers' sexual behavior differs from non-smokers. A two-stage stratified sampling was used to construct the individual-level JGSS data. ${ }^{4}$ The JGSS was conducted throughout Japan from 2000 to 2010. The JGSS included various questions concerning an individual's characteristics through face-to-face interviews. Hence, from the JGSS, I was able to source data regarding views on family issues such as how often people had sex over a year, smoking behavior, marital and demographic (age and sex) status, annual household income, ${ }^{5}$ years of schooling and political views. The JGSS dataset used in this study covered only 2000 and 2001 because a question about extramarital sex (used in this research) was only included in the 2000 and 2001 surveys. This paper attempts to investigate the determinants for how often people have sex.

The definitions of the basic statistics of the variables used in the regression estimations are shown in Table 1. In addition, a comparison of mean values for smokers and non-smokers is presented in Table 1. The key variables are Family satisfaction and Frequency of sex. In the JGSS, a question regarding divorce asked, "How much satisfaction do you get from your family life?" There are five response options, ranging from 1 (dissatisfied) to 5 (satisfied). Family satisfaction is the value that the respondents' chose. Concerning sexual behavior, respondents were asked, "How often did you have sex during the last 12 months?" There are eight response options: "Not at all", "Once or twice", "About once a month", "2-3 times a month", "About once a week", "2-3 times a week", "More than 3 times a week", and

\footnotetext{
${ }^{4}$ Data for this secondary analysis, "Japanese General Social Survey (JGSS), Ichiro Tanioka", was provided by the Social Science Japan Data Archive, Information Center for Social Science Research on Japan, Institute of Social Science, the University of Tokyo.

${ }^{5}$ In the original dataset, annual earnings were grouped into 19 categories, and we assumed that everyone in each category earned the midpoint value. For the top category of "23 million yen and above", it was assumed that everybody earned 23 million yen. Among observations used in the regression estimations, slightly less than $1 \%$ of observations occurred in this category. Therefore, the problem of top-coding should not be an issue.
} 
"Don't want to answer". With the exception of "Don't want to answer", frequency of sex can be calculated based on the respondents' response choices. In this paper, following the strategy taken by Genda (2010) using the same JGSS, each response was converted into how often respondents had sex over a 1-year period. ${ }^{6}$ Table 1 shows that the value of Family satisfaction for a smoker is 3.52 , which is slightly less than for a non-smoker (3.55). However, that of Frequency of sex for a smoker is 16.1, which is approximately 1.5 times more than that for a non-smoker (10.9). Values of Male for a smoker and non-smoker are 0.75 and 0.37 , respectively; implying that $75 \%$ of males are smokers while only $37 \%$ of females are smokers. That is, males are two times more likely to smoke than females in Japan. This is consistent with prior studies (Yamamura 2011).

Individuals' lifestyles are thought to be formed by the socio-economic situations in which they grew up. Japan experienced rapid economic growth after World War II. During this period, people's values changed significantly. In traditional Japanese society, the social status of males was higher than that of females. Hence, the behavior of females was limited and women could not behave like males even if they wanted to. In modern society, the differences between the social status of males and females have lessened. If the difference in smoking behavior between genders was because of the above limitation, then the gap in the rate of smoking between genders would be less. Table 2 shows that in each generation, males are more likely to be smokers than females. Furthermore, for both genders, the rate of smokers declines as people get older. The rate of male smokers aged 20-25 years old is approximately $62 \%$, which is approximately 1.5 times higher than that for males aged over 55 years old. In contrast, the rate of female smokers aged 20-25 years old is approximately $38 \%$, which is approximately four times higher than that for females aged over 55 years old. These results show that there is a much larger gap between generations for females than for males. In my interpretation, rapid economic development in the post-war period has changed a woman's social status, thus changing her lifestyle.

As explained above, the value of Frequency of sex is not a continuous variable. Table 3 contains data to better explain the situation. As mentioned earlier, Japanese people are less likely to have sex compared with people in Western countries. For instance, based on GSS data, only 18\% of respondents in the United

\footnotetext{
6 As approximated values, "Not at all", "Once or twice", "About once a month", "2-3 times a month", "About once a week", "2-3 times a week", "More than 3 times a week" are considered to be $0,1,3,24,52,104$ and 208, respectively.
} 
States of America had no sex during the surveyed 1-year period (Blanchflower and Oswald 2004). In comparison, based on the JGSS, a surprising $42.5 \%$ of Japanese people did not engage in sex over the previous 1-year period. Hence, Japanese people generally are less likely to be sexually active. Approximately $70 \%$ of unmarried people did not have sex at all whereas $32 \%$ of married people did not. Considering other annual sex rates, especially having sex 3, 24, or 52 times a year, the sex rates of married people are obviously higher than for unmarried people. The reason for this is that married people have a spouse who can be regarded as a sex partner. Hence, the situation in Japan is generally consistent with the United States of America (Blanchflower and Oswald 2004). Approximately 50\% of non-smokers did not have sex at all whereas $30 \%$ of smokers did not. Aside from those who had no sex, married people had more frequent sex than unmarried people. Further, smokers had more frequent sex than non-smokers. This suggests that smokers are more inclined to be sexually active than non-smokers.

Table 4 shows that the degree of family satisfaction for married smokers is higher than that for unmarried smokers and is statistically significant at the $1 \%$ level. Similarly, the degree of family satisfaction for married non-smokers is higher than that for unmarried non-smokers and is statistically significant at the $1 \%$ level. In contrast, concerning sexual behavior, it is interesting to observe that the frequency of sex for unmarried smokers is greater than that for married smokers and the difference is statistically significant at the $5 \%$ level. This is contrary to the findings of Blanchflower and Oswald (2004). On the other hand, the frequency of sex for married non-smokers is greater than that for unmarried non-smokers and shows a significant statistical difference. Thus, the existence of a spouse, who is a socially recognized sex partner, only increases the sex rate for non-smokers, which is consistent with intuition. However, for smokers, the existence of a spouse decreases sex frequency. In summary, whether married people are more likely to have sex depends on the individual's preference, captured by smoking behavior. This can be explained in part by the hypothesis proposed previously.

For a closer look into the differences between smokers' and non-smokers' sexual behaviors, a regression estimation is used.

\subsection{Econometric Framework and Estimation Strategy}


For the purpose of exploring how having sex affects family life satisfaction, the estimated function of the baseline model is as follows:

$$
\begin{aligned}
& \text { Family satisfaction } \mathrm{i}=\alpha_{1} \text { Frequency of sex } \mathrm{i}_{\mathrm{i}}+\alpha_{2} \text { Smoker }_{\mathrm{i}}+\alpha_{3} \text { Income }_{\mathrm{i}}+\alpha_{4} \text { Age }_{\mathrm{i}}+ \\
& \alpha_{5} \text { Married }_{\mathrm{i}}+\alpha_{6} \text { Child }_{i}+\alpha_{7} \text { Schooling }_{\mathrm{i}}+\alpha_{8} \text { Unemployed }_{\mathrm{i}}+\alpha_{9} \text { Male }_{\mathrm{i}}+\alpha_{10} \text { Health }_{\mathrm{i}}+ \\
& \mathrm{u}_{\mathrm{i}},
\end{aligned}
$$

where Family satisfaction i represents the dependent variable for individual i. Regression parameters are represented by $\alpha$. As explained earlier, values for Family satisfaction range from 1 to 5 , which can be regarded as an ordered response. In this case, the ordered probit model is applicable, and hence was used to conduct the estimations (Greene 1997). The error term is represented by $u_{i}$. During the study period, macro-economic conditions in Japan were thought to face various exogenous shocks. Macro-economic shocks appear to affect an individual's perception. Therefore, to include macro-economic shocks, this study included year dummies. ${ }^{7}$ In this specification, I attempt to examine how frequency of sex is associated with family satisfaction. Hence, the key variable is Frequency of sex. If the coefficient of Frequency of sex has the positive sign, having frequent sex leads people to be satisfied with their family life. Blanchflower and Oswald (2004) used dummy variables to capture frequency of sex because information regarding sexual activities is obtained by discrete choices. Hence, Blanchflower and Oswald (2004) included dummies to capture "Sex once or twice a year", "Sex once a month", "Sex 2-3 times a month", "Sex weekly", "Sex 2-3 times a week" and "Sex > = 4 times a week". Following Blanchflower and Oswald (2004), in alternative specifications, sexual behavior is captured by dummies rather than by Frequency of sex. Further, Smoker is included to compare smokers' and non-smokers' family satisfaction.

Following previous work (Blanchflower and Oswald 2004), various socio-economic factors are taken into account by incorporating various variables. Income and Unemployed are incorporated to capture economic condition effect.

\footnotetext{
${ }^{7}$ It is reasonable to assume that observations may be spatially correlated within an area. This is because the preference of one agent may be clearly related to the preference of another in the same area. To consider such a spatial correlation in line with this assumption, the Stata cluster command was used and z-statistics were calculated using robust standard errors. The advantage of this approach is that the magnitude of spatial correlation can be unique to each area. The JGSS data contains information about the prefecture where the respondent lives. A Japanese prefecture is considered to be the equivalent to a state in the United States of America or a province in Canada. Therefore, spatial correlation was assumed to be unique within the prefecture.
} 
Furthermore, the degree of education level captured by Schooling is thought to affect time preference and so is included. Further, Smoking seems to capture not only an individual's preference, but also health status because smoking behavior has a detrimental effect on health status. To indentify the effect of smoking, I included dummies for health status (Health_2, Health_3, Health_4, Health_5), where Health_1 is the reference group.

In addition to estimations for family satisfaction, for the purpose of assessing the previously proposed hypothesis, the estimated function of the baseline model is as follows:

Frequency of sex $_{\mathrm{i}}=b_{0}+b_{1}$ Smoker $_{\mathrm{i}}+B_{2}$ Income $_{\mathrm{i}}+B_{3}$ Age $_{\mathrm{i}}+b_{4}$ Married $_{\mathrm{i}}+b_{5}$ Child $_{\mathrm{i}}+$ $B_{6}$ Schooling $_{\mathrm{i}}+b_{7}$ Unemployed $_{\mathrm{i}}+B_{8}$ Male $_{\mathrm{i}}+B_{9}$ Health $_{\mathrm{i}}+\mathrm{u}_{\mathrm{i}}$.

In this model, the dependent variable is the frequency of sex. As explained earlier, concerning frequency of sex, respondents have eight choices; "Not at all", "Once or twice", "About once a month", "2-3 times a month", "About once a week", "2-3 times a week", "More than 3 times a week", and "Don't want to answer". This can be considered as interval-coded data because the quantitative outcome is grouped into intervals. Hence, I used an interval regression model, which is suitable to conduct estimations (Wooldridge 2002, p. 508-509).

The most important variable to determine how often respondents have sex is Smoker. Assuming that married people generally have sex with their spouse if Hypothesis 1 is supported (Smokers are less likely to have sex with their spouse), Smoker is predicted to have the negative sign based on the sub-sample of married people. ${ }^{8}$ Further, if Hypothesis 2 is supported (Smokers are more likely to have sex when they are unmarried), Smoker is predicted to have the positive sign based on the sub-sample of unmarried people.

As mentioned earlier, Table 4 shows that males are more likely to smoke than females, which is consistent with Yamamura (2011). Hence, smoking behavior is determined not only by innate individual preference but also by gender. In contrast, there seems to be a gender difference in the preference for sexual behavior. Accordingly, a gender difference possibly affects smoking behavior as well as frequency of sex. Therefore, it is important to control for gender differences to

8 It should be noted that married people could possibly have extramarital sex. However, because of the limitation of the data, I cannot distinguish how often people have sex with their spouse and extramarital sex. Hence, this paper is based on this strong assumption. 
avoid the possibility of a spurious correlation between smoking behavior and having sex. Accordingly, Male (male dummy) is included as an independent variable. Furthermore, following Genda (2010), various socio-economic factors are taken into account by incorporating variables such as Income, Age, Married, Schooling, and Unemployed. Education level is thought to influence sexual activities (Oettinger 1999), and hence Schooling is incorporated to capture the effect of education. Genda (2010) focused on how job status influences sexual behavior, showing that those who spend more time at work are less likely to have sex. If the time spent at work is included as an independent variable, the sample size decreases because this information is not available in this study. Instead, Unemployed is used to capture job status. In addition, physical condition affects the degree of sexual desire. Smokers are more inclined to suffer poor health and so their health status is worse than non-smokers. Hence, Smoker possibly captures not only an individual's preference but also health status, thereby affecting sexual behavior. With the aim of indentifying the effect of smoking, I included dummies for health status. The signs of health status dummies are predicted to become positive when good health status leads people to have sex. The older people are, the less their sexual desire. Age is included to control the decline of sexual desire. Smokers are thought to have low human capital and hence low income. Hence, inclusion of Income controls for such smokers' characteristics, reducing omitted variables bias.

\section{Estimation Results}

The results of Family satisfaction estimations are reported in Table 5(a) and (b). The results of Frequency of sex are shown in Tables 6, 7, 8 and 9. According to the specifications, the number of observations differ because data regarding some independent variables were not available for some observations. The results of the baseline model are reported in Table 6. In Tables 5 and 6, columns (1) and (2) present results based on the whole sample. Columns (3) and (4) present those for the married people sample while columns (5) and (6) present those for the unmarried sample. Tables 7, 8 and 9 show the results regarding the likelihood that a smoker spouse influences the effects of the respondent's smoking on his or her sexual behavior.

\subsection{Estimation results for marital satisfaction}


The results of the estimation ascertaining the determinants of family satisfaction are shown in Table 5(a). Frequency of sex shows the positive sign in all columns. Columns (1)-(4) exhibit statistical significance. However, Frequency of sex is not statistically significant in columns (5) and (6).

In Table 5(b), it can be noted from the results of the whole sample that the coefficient of each dummy for sex is positive and statistically significant, implying that when compared with those who did not have sex at all, people having sex are more likely to be satisfied with their family life. Hence, it is suggested that the more frequently people have sex, the more they are likely to feel family satisfaction. Clear results are also observed for the married people sample. In columns (3) and (4), the coefficient values of the dummies for frequency of sex become larger. It is interesting to observe that these coefficients have both negative and positive signs and are not statistically significant. This tells us that the rate of sex for unmarried people is not associated with family satisfaction. Thus, I derive the argument that the sex that married people engage in is more likely to be with a spouse and therefore having sex improves family satisfaction. If people have sex with someone other than their spouse in the case of unmarried people, then having sex has no effect on family satisfaction.

It follows then from the results in Table 5(a) and (b) that it is important to have sex with your spouse (and thereby maintain an intimate relationship) to improve the quality of family life.

\subsection{Estimation results for frequency of sex}

Table 6 suggests that the coefficient of Smoker has a negative sign and it is not statistically significant in columns (1) and (2). However, the coefficient of Smoker in columns (3) and (4) has a negative sign and is statistically significant at the $1 \%$ level. The absolute value of the coefficients is approximately 4 , indicating that the number of smokers having sex is smaller by 4 per year than non-smokers in the married people sample. In contrast, it is surprising to observe in columns (5) and (6) that the coefficient of Smoker has a positive sign and is statistically significant at the $1 \%$ level. The absolute values of the coefficients are approximately 8 , indicating that the number of smokers having sex is larger by 8 per year than non-smokers in the unmarried people sample. It follows then that smokers are more likely to have sex when they are unmarried and are less likely to have sex once they get married. Hence, these opposite effects of Smoker are 
neutralized when the whole sample is used. These results are consistent with Hypotheses 1 and 2.

Concerning the control variables, Married yields the positive sign and is statistically significant at the $1 \%$ level in columns (1) and (2). This implies that married people have their spouses who are considered as their official sex partners and so increases the opportunities to have sex. Unemployed shows a significant negative sign in columns (1) and (2), which is consistent with Genda (2010). Health_2, Health_3, Health_4 and Health_5 are not statistically significant in column (4). However, they have the positive sign and are statistically significant in column (6). This suggests that health status does not have an effect on the sexual behavior of married people, but has a positive effect on the sexual behavior of unmarried people.

It has been found that married people are more likely to be successful in smoking cessation than unmarried people (Jones 1994; Hsieh 1998; Feng 2005). There seems to be various spousal interaction effects on smoking behavior (Khwaja et al. 2006c). Smoking behavior results in a negative externality on surrounding people such as family members because of passive smoking. ${ }^{9}$ This offers smokers an incentive to reduce the detrimental effects of their smoking on their spouses. Hence, married smokers are more likely to stop smoking. In contrast, smokers' spouses have an incentive to improve their spouses' health status, which is harmed by smoking. Smokers therefore stop smoking thanks to the efforts of their spouses for the sake of the smokers' health. What is more, married people possibly learn from the experience of their spouses. In the case that spouses are smokers with poor health, married people see how smoking has harmed their spouses' health, increasing the risk of lung cancer, emphysema and other health problems. Thus, married people are less likely to smoke through experience and learning. On the other hand, smokers are more likely to marry smokers because people tend to marry those with similar preferences (Clark and Etile 2006). If this holds true, then the effect of spousal interaction would definitely decrease.

This paper is based on the assumption that time and risk preference can be captured by smoking behavior. However, various spousal interactions affect smoking behavior. Accordingly, whether people smoke or not depends to a certain extent on marital status, even when their time and risk preference is very stable

9 A mother's smoking during pregnancy is observed to have a detrimental effect on her newborn baby's health after giving birth (Colman et al. 2003; Sabia 2008). Children tend to inherit their mother's smoking habit (Sacerdote 2004). 
and not significantly influenced by the existence of a spouse. In particular, people's smoking behavior depends on the characteristics of their spouses. The spousal interaction effect inevitably poses some difficulty when interpreting the results in this paper. In this paper, I conjecture that a non-smoking wife does not want to have sex with her smoking husband because non-smokers dislike the smell of tobacco and are unwilling to have sex with smoking spouses. If this holds true, then the smaller number of smokers having sex is determined by their spouses' decision making rather than smokers' preference.

JGSS does not contain information regarding spouses' smoking behavior. As shown in Table 2, males are more likely to be smokers than females. Hence, the spouses of smoking males are less likely to be smokers. Using the married people sample, the interaction term between Smoker and Male (Smoker*Male) captures the effect of the wife of a male smoker having sex via a spousal interaction. If the coefficient of Smoker*Male has a significant negative sign, spousal interaction rather than smoker's preference will affect the frequency of sex. The result of Smoker* Male is reported in Table 7, with the estimations based on the married people sample. Table 2 further tells us that the older people are, the lower their smoking rate is. This result is more obvious for females. Age of spouse is considered to capture, to a certain extent, the probability of a spouse smoking. If the interaction term between Smoker and Wife's (husband's) age becomes statistically negative, spousal interaction rather than smoker's time and risk preference determines the frequency of sex. The results of estimations regarding the wife's effect are presented in Table 8 using the sample of married males, and the results of the estimations regarding the husband's effect is presented in Table 9 using the sample of married females.

It is shown in Table 7 that Smoker*Male produces the positive sign in columns (1) and (2), which does not support the conjecture that spousal interaction reduces frequency of sex. Smoker*Male is statistically significant at the $10 \%$ level in column (1), although after controlling for health status it is not statistically significant. The positive sign of Smoker*Male implies that female smokers are less likely to have sex with their spouses than male smokers. In my interpretation, whether one smokes or not might be in part because of the possibility that one's colleague smokes. The smoking behavior of a male is determined not only by his preference but also by his smoking male colleague. Hence, there is the possibility that males smoke even when their discount rate is low. In contrast, female smoking behavior more accurately reflects her own preference than males because 
her female colleague is unlikely to smoke and so there is no peer effect. Accordingly, female smokers have higher individual discount rates than male smokers, reducing the investment in spousal relationships.

Table 8 shows that Smoker*Wife's age yields the positive sign and is statistically insignificant. Table 9 tells us that Smoker*husband's age also produces the positive sign and is statistically insignificant. The results of Tables 8 and 9 lead me to argue that a smoker's sexual behavior with his (her) spouse is not influenced by the likelihood of his (her) spouse's smoking. Considering the results of Tables 7-9 jointly implies that spousal interaction does not influence the frequency of sex. Hence, the effect of Smoker on frequency of sex is thought to reflect a smoker's time and risk preference for an investment in "family capital".

The combined results of Tables 5-10 strongly support Hypotheses 1 and 2 proposed in Section 2. What is more, smokers tend to reduce family satisfaction as they are less likely to have sex with their spouse. From this, I derive the argument that smokers have a detrimental effect on their family not only through passive smoking but also through poor efforts to maintain intimate relations with their spouse.

\section{Conclusions and policy implications}

Existing literature has made it evident that smokers are more present-oriented and so are unlikely to invest in future expected benefits. Furthermore, smokers have an inclination to behave as risk takers. The preferences of smokers therefore provide us with important information, creating expectations that smokers' behavior will differ from non-smokers. For instance, the characteristics of smokers described above are thought to hamper marital life because it is considered important for married people to invest in their relationship with their spouse to help them better cope with risk or to increase their benefits in the future. However, there is currently no research on this topic. Hence, the present study is the first to examine how smokers' sexual behavior differs from non-smokers using JGSS data from Japan. I found the following using interval regression and ordered probit estimations: (1) frequency of sex is positively associated with family satisfaction, (2) smokers are more likely to have sex than non-smokers when they are not married and (3) smokers are less likely to have sex than non-smokers when they are married.

The results of this study lead me to derive the argument that whether one is 
a smoker provides unmarried people with important information when selecting their partners. Information asymmetry between men and women means that the marriage market does not function smoothly when people search for partners. That is, before marriage, suitors are not able to obtain sufficient information about their possible partners, and thus suitors are hesitant to marry. Hence, marriage rates inevitably decrease. Even if suitors have married, they may possibly later find fault with their spouses' characters. For instance, generally, a suitor does not confess that he is unwilling to make an effort to maintain a good relationship with his spouse, even if he think so when he approaches a woman with the aim of marriage. In such a case, there is the possibility that they will eventually get divorced. This can be considered as a mismatch in the marriage market. Smoking behavior alerts us to his unobserved characteristics before marriage, thus reducing information asymmetry. If a man smokes on a date with a woman, she becomes aware of his concealed preference and can predict his perfunctory attitude if they get married. Even in the case that the boyfriend does not smoke in his girlfriend's presence, the smell of cigarettes will be detected and so she can predict that she will be dissatisfied with her marital life.

It is useful to consider smoking behavior in the marriage market to reduce hesitation regarding marriage and to reduce mismatches and divorce. This, in turn, will raise fertility rates. Maintaining good relationships between parents with frequent sex is thought to have a positive effect on their child.

There are some caveats in the analysis of this paper. First, this paper divides the sample into married and unmarried groups and then compares smokers' effect on frequency of sex between the two groups. However, people have to make a decision about marriage. Inevitably, the results of this paper suffer from selection bias. However, the problem of the selection bias has not been addressed here. Second, time preference cannot be directly observed and so this paper considers smoking behavior to capture preference. However, some of the control variables seem to correlate with the preference, resulting in estimation bias (Munasinghe and Sicherman 2006). These remaining issues should be addressed in future research. 


\section{References}

Anderson, L. R., and Mellor, J. (2008). Predicting health behaviors with an experimental measure of risk preference. Journal of Health Economics 27, 1260-1274.

Averett S. L., Rees D., Duncan B., and Argys L.M. (2004). Race, ethnicity, and gender differences in the relationship between substance use and adolescent sexual behavior. The B.E. J of Econ Analysis \& Policy. 0(1).

Becker, G. (1974). A theory of marriage. In Economics of Family, edited by T.W. Schultz. Chicago: University Chicago Press.

Becker, G. (1983). A Treatise on the Family. England ed. Harvard University Press, Cambridge.

Becker, G., Landes, E. and Michael, R. (1977). An economic analysis of marital instability. Journal of Political Economy 85(6), 1411-1187.

Blanchflower, D.G. and Oswald, A.G. (2004). Money, sex and happiness: an empirical study. Scandinavian Journal of Economics 106(3), 393-415.

Carpenter, G. (2005). Youth alcohol use and risky sexual behavior: evidence from underage drunk driving lows. Journal of Health Economics 24(3), 613-628.

Chesson, H., Harrison, P., Kassler, W.J. (2000). Sex under the influence: the effect of alcohol policy on sexually transmitted disease rates in the United States. Journal of Law \& Economics 43, 215-238.

Clark, A.E., Etile, F. (2006). Don't give up on me baby: spousal correlation in smoking behavior. Journal of Health Economics 25, 958-978.

Colman, G., Grossman,M., and Joyce,T (2003). The effect of cigarette excise taxes on smoking before, during and after pregnancy. Journal of Health Economics 22, 1053-1072.

Drakopoulos, A. S. (2010). Economic Policies, Socieconomic Factors and Overall Health: A Short Review, EERI Research Paper 2010/13, Economics and Econometrics Research Institute (EERI), Brussels.

Feng, S. (2005). Rationality and self-control: the implications for smoking cessation. Journal of Socio- Economics 34, 211-222.

Francesconi, M. (2008). Adult outcomes for children of teenage mothers. Scandinavian Journal of Economics, 110(1), 93-117.

Genda,Y. (2010). Ningen ni Kaku wa nai: Ishikawa Tsuneo to 2000 nen dai no Rodoshijo. 8 Sho. (In Japanese). [There is No Status among People: Tsuneo 
Ishikawa and Labor Market in 2000s: Chapter 8], Mineruva Shobo, Kyoto.

Grossman, M., Kaestner, R., and Markowitz, S. (2004). Get high and get stupid: The effect of alcohol and marijuana use on teen sexual behavior. Review of Economics of Household 2(4), 413-441.

Grossman, M.and Markowitz, S. (2005). I did what last night? Adolescence risky sexual behaviors and substance use. Eastern Economic Journal 31(3), 383-405.

Greene, W. (1997). Econometric Analysis (3 eds). London. Prentice-Hall.

Glaeser, E.L., Laibson, D., and Sacerdote, B. (2002). An economic approach to social capital. Economic Journal, 122, F437-F458.

Harrison, G.,W., Lau, M.I., Williams, M.B (2010). Individual discount rates and smoking: Evidence from a field experiment in Denmark. Journal of Health Economics 29, 708-717.

Hersch, J. (1996). Smoking, seat belts, and other risky consumer decisions: differences by gender and race. Managerial and Decision Economics, 471-481.

Hersch, J. and Viscussi, W.K. (1990).Cigarette smoking, seatbelt use, and differences in wage-risk tradoffs. Journal of Human Resource 202-227.

Hsieh, C.R. (1998). Health risk and the decision to quit smoking. Applied Economics, 30, 795-804.

Ida, T., and Goto, R. (2009a). Simultaneous measurement of time and risk preferences: Stated preference discrete choice modeling analysis depending on smoking behavior. International Economic Review 50, 1169-1182.

Ida, T., and Goto, R. (2009b). Interdependency among addictive behaviours and time/risk preferences: discrete choice model analysis of smoking, drinking and gambling. J ournal of Economic Psychology 30, 608-621.

Jones, A.M. (1994). Health, addiction, social interaction and the decision to quit smoking. Journal of Health Economics 13, 93-110.

Levine, P.B., Gustafson, T.A. and Velenchik A.D. (1997). More bad news for smokers? The effects of cigarette smoking on wages. Industrial and Labor Relation Review, 493-509.

Lucas, R.E., Clark, A, E., Georgellis, Y. and Diener, E. (2003). Reexamining adaptation and the set model of happiness: reaction to change in marital status. Journal of Personality and social psychology 84, 527-536.

Kancs, D 2011. "Labour Migration in the Enlarged EU: A New Economic 
Geography Approach," Journal of Economic Policy Reform 14, 171-188.

Khwaja, A., Sloan, F. and Salm, M. (2006a). Evidence on preferences and subjective beliefs of risk takers: The case of smokers. International Journal of Industrial Organization 24, 667-682.

Khwaja, A., Sloan, F. and Chung, S. (2006b). Learning about individual risk and decision to smoke. International Journal of Industrial Organization 24, 683-699.

Khwaja, A., Sloan, F. and Chung, S. (2006c).The effects of spousal health on the decision to smoke: evidence on consumption externalities, altruism and learning within the household. Journal of Risk and Uncertainty, 32, 17-35.

Markowitz, R., Kaestner, R. and Grossman, M. (2005). An investigation of the effects of alcohol consumption and alcohol policies on youth risky sexual behaviors. American Economic Review 95(2), 263-266.

Mialon, H.M. (2012). The economics of faking ecstasy. Economic Inquiry 50(1), 277-285.

Munasinghe, L. and Sicherman, N. (2006). Why do dancers smoke? Smoking, time preference, and wage dynamics. Eastern Economic Journal 32, 595-616.

Oettinger, G.S. (1999). The effects of sex education on teen sexual activity and teen pregnancy. Journal of Political Economy 107, 606-644.

Pfarr C., A. Schmid, U. Schneider, (2011). Estimating ordered categorical variables using panel data: a generalized ordered probit model with an autofit procedure, J ournal of Economics and Econometrics, 54(1), 7-23.

Putnam, R. (1993). Making Democracy Work: Civic Traditions in Modern Italy. Princeton: Princeton University Press.

Putnam, R. (2000). Bowling Alone: The Collapse and Revival of American Community, A Touchstone Book, New York.

Rees, D., Argys L, M. and Averett S. L (2001). New evidence on the relationship between substance use and adolescent sexual behavior. Journal Health Economics 20(5), 835-845.

Sabia, J.J. (2008). Every breath you take: the effect of postpartum maternal smoking on childhood asthma. Southern Economic J ournal 75, 128-158.

Sacerdote, B. (2004). What happens when we randomly assign children to family? NBER working papers 10894.

Sato, M., and Ohukusa, Y. (2003). The relationship between smoking initiation and time discount factor, risk aversion and information. Applied Economics 
Letters 10, 287-289.

Sen B (2002) Does alcohol-use increase the risk of sexual intercourse among adolescents? Evidence from the NLSY97. Journal of Health Economics 21(6), 1085-1093.

Sen B. (2003). Can beer taxes affect teen pregnancy? Evidence based on teen abortion rates and birth rates. Southern Economic J ournal 70(2), 328-343.

Stutzer, A., Frey, B. (2006). Does marriage make happy, or do happy people get married? Journal of Socio-economics 35, 326-347.

Viscussi, W.K. and Hersch, J. (2001). Cigarette smoking as job risk takers. Review of Economics and Statistics, 269-280

Waddell, G.R. (2012). Gender and the influence of peer alcohol consumption on adolescent sexual activity. Economic Inquiry 50(1), 248-263.

Wooldridge, J. (2002). Econometric Analysis of Cross Section and Panel Data, London, MIT Press.

Yamamura,E. (2011). Different effects of social capital on health status among residents: Evidence from modern Japan, Journal of Socio- Economics, 40(5), 475-479.

Yamamura,E. (2011). The effects of the social norm on cigarette consumption: evidence from Japan using panel data. Japan \& World Economy 23(1), 6-12. 
Table 1

Basic statistics and definitions of variables used for estimations

\begin{tabular}{|c|c|c|c|}
\hline & Definitions & Smoker & $\begin{array}{l}\text { Non- } \\
\text { smoker }\end{array}$ \\
\hline $\begin{array}{l}\text { Family } \\
\text { satisfaction }\end{array}$ & $\begin{array}{l}\text { Degree of family life satisfaction } \\
1 \text { (Dissatisfied)-5 (Satisfied) }\end{array}$ & 3.52 & 3.55 \\
\hline Frequency of sex & $\begin{array}{l}\text { Question: How often did you have sex during the last } 12 \text { months? } \\
\text { Number of times respondent had sex during the last } 12 \text { months }\end{array}$ & 16.1 & 10.9 \\
\hline Smoker & The value is 1 if the respondent is currently a smoker, otherwise 0 & 1 & 0 \\
\hline Income & $\begin{array}{l}\text { Individual household income } \\
\text { (million yen) }\end{array}$ & 664 & 636 \\
\hline Age & Age (years) & 48.5 & 56.4 \\
\hline Married & The value is 1 if the respondent is currently married, otherwise 0 & 0.73 & 0.71 \\
\hline Child & Number of children & 1.63 & 1.93 \\
\hline Schooling & Years of schooling & 12.0 & 11.5 \\
\hline Unemployed & $\begin{array}{l}\text { The value is } 1 \text { if the respondent is currently unemployed, } \\
\text { otherwise } 0\end{array}$ & 0.02 & 0.01 \\
\hline Male & The value is 1 if the respondent is male, otherwise 0 & 0.75 & 0.37 \\
\hline Health_1 & $\begin{array}{l}\text { Concerning health condition, it takes } 1 \text { if respondents choose } 1 \text {, } \\
\text { otherwise } 0 ; 1 \text { (poor)-5 (good) }\end{array}$ & 0.02 & 0.08 \\
\hline Health_2 & $\begin{array}{l}\text { Concerning health condition, it takes } 1 \text { if respondents choose } 2 \text {, } \\
\text { otherwise } 0 ; 1 \text { (poor)-5 (good) }\end{array}$ & 0.15 & 0.18 \\
\hline Health_3 & $\begin{array}{l}\text { Concerning health condition, it takes } 1 \text { if respondents choose } 3 \text {, } \\
\text { otherwise } 0 ; 1 \text { (poor)-5 (good) }\end{array}$ & 0.33 & 0.31 \\
\hline Health_4 & $\begin{array}{l}\text { Concerning health condition, it takes } 1 \text { if respondents choose } 4 \text {, } \\
\text { otherwise } 0 ; 1 \text { (poor)-5 (good) }\end{array}$ & 0.23 & 0.22 \\
\hline Health_5 & $\begin{array}{l}\text { Concerning health condition, it takes } 1 \text { if respondents choose } 5 \text {, } \\
\text { otherwise } 0 ; 1 \text { (poor)-5 (good) }\end{array}$ & 0.22 & 0.21 \\
\hline
\end{tabular}

Sample is used for baseline estimations presented in column (1), Table 4. 
Table 2

\begin{tabular}{lrr}
\multicolumn{3}{c}{ Rate of smokers $(\%)$} \\
\hline Age & Male & \multicolumn{1}{c}{ Female } \\
\hline 20-25 years & 61.6 & 37.6 \\
26-35 years & 54.8 & 27.3 \\
36-45 years & 60.3 & 22.0 \\
46-55 years & 55.2 & 18.9 \\
55+ years old & 40.3 & 9.7
\end{tabular}

Sample is used for baseline estimations presented in column (1), Table 4. 
Table 3

Distribution of frequency of sex (\%)

\begin{tabular}{lccccc}
\hline $\begin{array}{l}\text { Number of } \\
\text { times } \\
\text { respondent } \\
\text { had sex over } \\
12 \text { months }\end{array}$ & & Married & Unmarried & Smoker & $\begin{array}{l}\text { Non-smok } \\
\text { er }\end{array}$ \\
\hline 0 & 42.5 & 32.2 & 69.6 & 29.3 & 48.9 \\
1 & 11.1 & 12.9 & 6.2 & 13.8 & 9.7 \\
3 & 18.3 & 22.5 & 7.2 & 22.7 & 16.1 \\
24 & 16.6 & 19.7 & 8.6 & 19.4 & 15.3 \\
52 & 8.7 & 9.8 & 5.7 & 10.5 & 7.8 \\
104 & 2.5 & 2.6 & 2.2 & 3.7 & 1.9 \\
208 & 0.4 & 0.4 & 0.5 & 0.6 & 0.3
\end{tabular}

Sample is used for baseline estimations presented in column (1), Table 4. 
Table 4

Mean difference tests for family satisfaction and frequency of sex

(1) Married vs. Unmarried people

\begin{tabular}{lccc}
\hline & Married & Unmarried & t-statistics \\
\cline { 1 - 1 } Sample of smokers & 3.59 & 3.33 & $4.00^{* * *}$ \\
Family satisfaction & 15.2 & 18.4 & $-1.67^{*}$ \\
Frequency of sex & 3.59 & 3.45 & $2.89^{* * *}$ \\
\cline { 1 - 1 } Sample of non-smokers & 13.5 & 4.17 & $7.33^{* * *}$ \\
\hline Family satisfaction & & & \\
\hline
\end{tabular}

*** and * indicates significance at the $1 \%$ and $10 \%$ levels, respectively. 
Table 5(a) Regression estimation where the dependent variable is Family satisfaction (ordered probit model)

\begin{tabular}{|c|c|c|c|c|c|c|}
\hline \multirow{3}{*}{ Frequency of sex } & \multicolumn{2}{|c|}{ Whole sample } & \multicolumn{2}{|c|}{ Married people } & \multicolumn{2}{|c|}{ Unmarried people } \\
\hline & (1) & (2) & (3) & (4) & (5) & (6) \\
\hline & $\begin{array}{c}0.004^{* * *} \\
(4.04)\end{array}$ & $\begin{array}{c}0.003^{* * * *} \\
(3.31)\end{array}$ & $\begin{array}{c}0.004^{* * * *} \\
(4.56)\end{array}$ & $\begin{array}{l}0.003^{* * * *} \\
(4.02)\end{array}$ & $\begin{array}{l}0.001 \\
(0.81)\end{array}$ & $\begin{array}{l}0.0007 \\
(0.38)\end{array}$ \\
\hline Smoker & $\begin{array}{l}-0.04 \\
(-0.93)\end{array}$ & $\begin{array}{l}-0.04 \\
(-1.09)\end{array}$ & $\begin{array}{l}-0.01 \\
(-0.24)\end{array}$ & $\begin{array}{l}-0.01 \\
(-0.32)\end{array}$ & $\begin{array}{l}-0.15^{*} \\
(-1.68)\end{array}$ & $\begin{array}{l}-0.16 \\
(-1.63)\end{array}$ \\
\hline Income & $\begin{array}{c}0.29 * * * \\
(6.25)\end{array}$ & $\begin{array}{c}0.23 * * * \\
(5.22)\end{array}$ & $\begin{array}{c}0.26^{* * *} \\
(3.89)\end{array}$ & $\begin{array}{c}0.20 * * * \\
(3.29)\end{array}$ & $\begin{array}{c}0.42^{* * * *} \\
(3.90)\end{array}$ & $\begin{array}{c}0.36^{* * * *} \\
(3.33)\end{array}$ \\
\hline Age & $\begin{array}{l}0.001 \\
(0.88)\end{array}$ & $\begin{array}{l}0.003^{*} \\
(1.94)\end{array}$ & $\begin{array}{l}0.001 \\
(0.05)\end{array}$ & $\begin{array}{l}0.001 \\
(0.81)\end{array}$ & $\begin{array}{l}-0.001 \\
(-0.35)\end{array}$ & $\begin{array}{l}0.001 \\
(0.19)\end{array}$ \\
\hline Married & $\begin{array}{l}0.13^{* *} \\
(2.18)\end{array}$ & $\begin{array}{c}0.17 * * * \\
(2.91)\end{array}$ & & & & \\
\hline Child & $\begin{array}{l}-0.01 \\
(-0.26)\end{array}$ & $\begin{array}{l}-0.01 \\
(-0.75)\end{array}$ & $\begin{array}{l}-0.03 \\
(-1.26)\end{array}$ & $\begin{array}{l}-0.04 \\
(-1.49)\end{array}$ & $\begin{array}{c}0.02 \\
(0.45)\end{array}$ & $\begin{array}{l}-0.01 \\
(-0.14)\end{array}$ \\
\hline Schooling & $\begin{array}{c}0.01 \\
(1.42)\end{array}$ & $\begin{array}{c}0.01 \\
(0.78)\end{array}$ & $\begin{array}{c}0.01 \\
(1.11)\end{array}$ & $\begin{array}{c}0.01 \\
(0.63)\end{array}$ & $\begin{array}{c}0.01 \\
(0.34)\end{array}$ & $\begin{array}{l}0.002 \\
(0.08)\end{array}$ \\
\hline Unemployed & $\begin{array}{l}-0.32^{* *} \\
(-2.18)\end{array}$ & $\begin{array}{l}-0.39 * * * \\
(-2.67)\end{array}$ & $\begin{array}{l}-0.19 \\
(-0.90)\end{array}$ & $\begin{array}{l}-0.34^{*} \\
(-1.72)\end{array}$ & $\begin{array}{l}-0.50^{* *} \\
(-2.28)\end{array}$ & $\begin{array}{l}-0.45^{*} \\
(-1.83)\end{array}$ \\
\hline Male & $\begin{array}{l}-0.001 \\
(-0.04)\end{array}$ & $\begin{array}{c}0.03 \\
(0.71)\end{array}$ & $\begin{array}{c}0.09 \\
(1.55)\end{array}$ & $\begin{array}{l}0.15^{* *} \\
(2.57)\end{array}$ & $\begin{array}{c}-0.32^{* * *} \\
(-3.80)\end{array}$ & $\begin{array}{c}-0.33^{* * *} \\
(-3.38)\end{array}$ \\
\hline Health_1 & Referer & group & Reference & oup & Reference g & \\
\hline Health_2 & & $\begin{array}{l}0.31^{* * *} \\
(3.13)\end{array}$ & & $\begin{array}{l}0.18^{*} \\
(1.73)\end{array}$ & & $\begin{array}{l}0.70^{* * * *} \\
(3.43)\end{array}$ \\
\hline Health_3 & & $\begin{array}{l}0.40^{* * * *} \\
(4.33)\end{array}$ & & $\begin{array}{l}0.29^{* * * *} \\
(3.38)\end{array}$ & & $\begin{array}{l}0.66^{* * *} \\
(3.34)\end{array}$ \\
\hline Health_4 & & $\begin{array}{l}0.79 * * * \\
(7.96)\end{array}$ & & $\begin{array}{l}0.75^{* * * *} \\
(8.78)\end{array}$ & & $\begin{array}{l}0.86^{* * * *} \\
(3.72)\end{array}$ \\
\hline Health_5 & & $\begin{array}{l}1.15^{* * * *} \\
(12.7)\end{array}$ & & $\begin{array}{l}1.10^{* * *} \\
(13.9)\end{array}$ & & $\begin{array}{l}1.31^{* * *} \\
(5.65)\end{array}$ \\
\hline $\begin{array}{l}\text { Log } \\
\text { pseudo-likelihood }\end{array}$ & $-3,313$ & $-3,192$ & $-2,570$ & $-2,468$ & -726 & -700 \\
\hline Observations & 2,461 & 2,460 & 1,921 & 1,921 & 540 & 539 \\
\hline
\end{tabular}

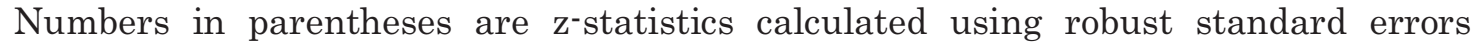
clustered in the prefecture. ${ }^{*}, * *$, and $* * *$ indicate significance at the $10 \%, 5 \%$, and $1 \%$ levels, respectively. In all estimations, year dummies were included as independent variables, but they are not reported because of space limitations. 
Table 5(b) Regression estimation where the dependent variable is Family satisfaction (ordered probit model)

\begin{tabular}{|c|c|c|c|c|c|c|}
\hline \multirow{3}{*}{$\begin{array}{l}\text { Frequency of } \\
\text { sex_o }\end{array}$} & \multicolumn{2}{|c|}{ Whole sample } & \multicolumn{2}{|c|}{ Married people } & \multicolumn{2}{|c|}{ Unmarried people } \\
\hline & (1) & (2) & (3) & (4) & (5) & (6) \\
\hline & \multicolumn{2}{|c|}{ Reference group } & \multicolumn{2}{|c|}{ Reference group } & \multicolumn{2}{|c|}{ Reference group } \\
\hline $\begin{array}{l}\text { Frequency of } \\
\text { sex_1 }\end{array}$ & $\begin{array}{c}0.04 \\
(0.63)\end{array}$ & $\begin{array}{c}0.03 \\
(0.49)\end{array}$ & $\begin{array}{c}0.11 \\
(1.31)\end{array}$ & $\begin{array}{c}0.09 \\
(1.18)\end{array}$ & $\begin{array}{l}-0.06 \\
(-0.53)\end{array}$ & $\begin{array}{l}-0.06 \\
(-0.59)\end{array}$ \\
\hline $\begin{array}{l}\text { Frequency of } \\
\text { sex_3 }\end{array}$ & $\begin{array}{l}0.14^{* *} \\
(2.55)\end{array}$ & $\begin{array}{l}0.12^{* *} \\
(2.45)\end{array}$ & $\begin{array}{c}0.18^{* * * *} \\
(2.81)\end{array}$ & $\begin{array}{c}0.15^{* *} \\
(2.44)\end{array}$ & $\begin{array}{c}0.14 \\
(0.74)\end{array}$ & $\begin{array}{c}0.18 \\
(0.98)\end{array}$ \\
\hline $\begin{array}{l}\text { Frequency of } \\
\text { sex_24 }\end{array}$ & $\begin{array}{l}0.12^{*} \\
(1.76)\end{array}$ & $\begin{array}{c}0.10 \\
(1.61)\end{array}$ & $\begin{array}{l}0.17^{* *} \\
(2.59)\end{array}$ & $\begin{array}{c}0.15^{* *} \\
(2.39)\end{array}$ & $\begin{array}{l}-0.05 \\
(-0.26)\end{array}$ & $\begin{array}{l}-0.06 \\
(-0.29)\end{array}$ \\
\hline $\begin{array}{l}\text { Frequency of } \\
\text { sex_52 }\end{array}$ & $\begin{array}{c}0.36^{* * *} \\
(4.62)\end{array}$ & $\begin{array}{c}0.29 * * * \\
(3.56)\end{array}$ & $\begin{array}{l}0.44^{* * * *} \\
(5.11)\end{array}$ & $\begin{array}{c}0.33^{* * *} \\
(3.74)\end{array}$ & $\begin{array}{c}0.05 \\
(0.27)\end{array}$ & $\begin{array}{c}0.06 \\
(0.36)\end{array}$ \\
\hline $\begin{array}{l}\text { Frequency of } \\
\text { sex_104 }\end{array}$ & $\begin{array}{c}0.50^{* * * *} \\
(4.07)\end{array}$ & $\begin{array}{c}0.39 * * * \\
(3.31)\end{array}$ & $\begin{array}{c}0.54^{* * * *} \\
(3.87)\end{array}$ & $\begin{array}{c}0.41 * * * \\
(3.02)\end{array}$ & $\begin{array}{c}0.38 \\
(1.29)\end{array}$ & $\begin{array}{c}0.27 \\
(1.03)\end{array}$ \\
\hline $\begin{array}{l}\text { Frequency of } \\
\text { sex_208 }\end{array}$ & $\begin{array}{l}0.68^{*} \\
(1.71)\end{array}$ & $\begin{array}{c}0.61 \\
(1.38)\end{array}$ & $\begin{array}{c}0.92^{* *} \\
(2.27)\end{array}$ & $\begin{array}{c}0.90^{* *} \\
(2.07)\end{array}$ & $\begin{array}{c}0.14 \\
(0.19)\end{array}$ & $\begin{array}{c}-0.08 \\
(-0.11)\end{array}$ \\
\hline Smoker & $\begin{array}{l}-0.05 \\
(-1.05)\end{array}$ & $\begin{array}{l}-0.05 \\
(-1.18)\end{array}$ & $\begin{array}{l}-0.01 \\
(-0.24)\end{array}$ & $\begin{array}{l}-0.02 \\
(-0.39)\end{array}$ & $\begin{array}{l}-0.16^{*} \\
(-1.70)\end{array}$ & $\begin{array}{l}-0.17 \\
(-1.63)\end{array}$ \\
\hline Income & $\begin{array}{c}0.28^{* * * *} \\
(6.09)\end{array}$ & $\begin{array}{c}0.22 * * * \\
(5.07)\end{array}$ & $\begin{array}{c}0.25^{* * *} \\
(3.68)\end{array}$ & $\begin{array}{c}0.19 * * * \\
(3.10)\end{array}$ & $\begin{array}{c}0.43^{* * *} \\
(3.64)\end{array}$ & $\begin{array}{c}0.36^{* * *} \\
(3.11)\end{array}$ \\
\hline Age & $\begin{array}{l}0.002 \\
(1.42)\end{array}$ & $\begin{array}{c}0.004^{* *} \\
(2.42)\end{array}$ & $\begin{array}{l}0.001 \\
(0.78)\end{array}$ & $\begin{array}{l}0.003 \\
(1.45)\end{array}$ & $\begin{array}{l}-0.001 \\
(-0.32)\end{array}$ & $\begin{array}{l}0.001 \\
(0.28)\end{array}$ \\
\hline Married & $\begin{array}{l}0.10^{*} \\
(1.78)\end{array}$ & $\begin{array}{l}0.15^{* *} \\
(2.47)\end{array}$ & & & & \\
\hline Child & $\begin{array}{l}-0.01 \\
(-0.44)\end{array}$ & $\begin{array}{l}-0.02 \\
(-0.90)\end{array}$ & $\begin{array}{l}-0.04 \\
(-1.55)\end{array}$ & $\begin{array}{l}-0.04^{*} \\
(-1.68)\end{array}$ & $\begin{array}{c}0.02 \\
(0.47)\end{array}$ & $\begin{array}{l}-0.01 \\
(-0.11)\end{array}$ \\
\hline Schooling & $\begin{array}{c}0.01 \\
(1.31)\end{array}$ & $\begin{array}{c}0.01 \\
(0.70)\end{array}$ & $\begin{array}{c}0.01 \\
(0.98)\end{array}$ & $\begin{array}{c}0.01 \\
(0.53)\end{array}$ & $\begin{array}{c}0.01 \\
(0.38)\end{array}$ & $\begin{array}{l}0.003 \\
(0.11)\end{array}$ \\
\hline Unemployed & $\begin{array}{c}-0.31^{* *} \\
(-2.18)\end{array}$ & $\begin{array}{c}-0.38^{* * *} \\
(-2.69)\end{array}$ & $\begin{array}{l}-0.19 \\
(-0.90)\end{array}$ & $\begin{array}{l}-0.34^{*} \\
(-1.72)\end{array}$ & $\begin{array}{l}-0.50^{* *} \\
(-2.23)\end{array}$ & $\begin{array}{l}-0.44^{*} \\
(-1.81)\end{array}$ \\
\hline Male & $\begin{array}{l}-0.005 \\
(-0.13)\end{array}$ & $\begin{array}{c}0.02 \\
(0.63)\end{array}$ & $\begin{array}{c}0.08 \\
(1.41)\end{array}$ & $\begin{array}{c}0.14^{* *} \\
(2.44)\end{array}$ & $\begin{array}{c}-0.31^{* * *} \\
(-3.33)\end{array}$ & $\begin{array}{c}-0.32^{* * * *} \\
(-2.98)\end{array}$ \\
\hline Health_1 & \multicolumn{2}{|c|}{ Reference group } & \multicolumn{2}{|c|}{ Reference group } & \multicolumn{2}{|c|}{ Reference group } \\
\hline Health_2 & & $\begin{array}{l}0.31^{* * * *} \\
(3.18)\end{array}$ & & $\begin{array}{l}0.17^{*} \\
(1.72)\end{array}$ & & $\begin{array}{l}0.70 * * * * \\
(3.44)\end{array}$ \\
\hline Health_3 & & $\begin{array}{l}0.40^{* * * *} \\
(4.32)\end{array}$ & & $\begin{array}{l}0.29 * * * * \\
(3.31)\end{array}$ & & $\begin{array}{l}0.65^{* * * *} \\
(3.34)\end{array}$ \\
\hline Health_4 & & $\begin{array}{l}0.78^{* * * *} \\
(8.07)\end{array}$ & & $\begin{array}{l}0.75^{* * * *} \\
(8.81)\end{array}$ & & $\begin{array}{l}0.87^{* * * *} \\
(3.82)\end{array}$ \\
\hline Health_5 & & $\begin{array}{l}1.15^{* * *} \\
(12.7)\end{array}$ & & $\begin{array}{l}1.09^{* * * *} \\
(13.6)\end{array}$ & & $\begin{array}{l}1.31^{* * * *} \\
(5.66)\end{array}$ \\
\hline $\log$ & $-3,310$ & $-3,190$ & $-2,566$ & $-2,465$ & -725 & -699 \\
\hline
\end{tabular}

pseudo-likelihood 
Frequency of sex_O is a dummy variable that takes 1 when a respondent had no sex at all during the last 12 months, otherwise 0. Frequency of sex_1 is a dummy variable that takes 1 when a respondent had sex just one time during the last 12 months, otherwise 0 . Frequency of sex_3 is a dummy variable that takes 1 when a respondent had sex 3 times during the last 12 months, otherwise 0. Frequency of sex_24 is a dummy variable that takes 1 when a respondent had sex 24 times during the last 12 months, otherwise 0. Frequency of sex_52 is a dummy variable that takes 1 when a respondent had sex 52 times during the last 12 months, otherwise 0. Frequency of sex_104 is a dummy variable that takes 1 when a respondent had sex 104 times during the last 12 months, otherwise 0. Frequency of sex_208 is a dummy variable that takes 1 when a respondent had sex 208 times during the last 12 months, otherwise 0. Numbers in parentheses are $\mathrm{z}$-statistics calculated using robust standard errors clustered in the prefecture. ${ }^{*}, * *$, and $* * *$ indicate significance at the $10 \%, 5 \%$, and $1 \%$ levels, respectively. In all estimations, year dummies were included as independent variables, but they are not reported because of space limitations. 
Table 6 Regression estimation where the dependent variable is Frequency of sex (interval model)

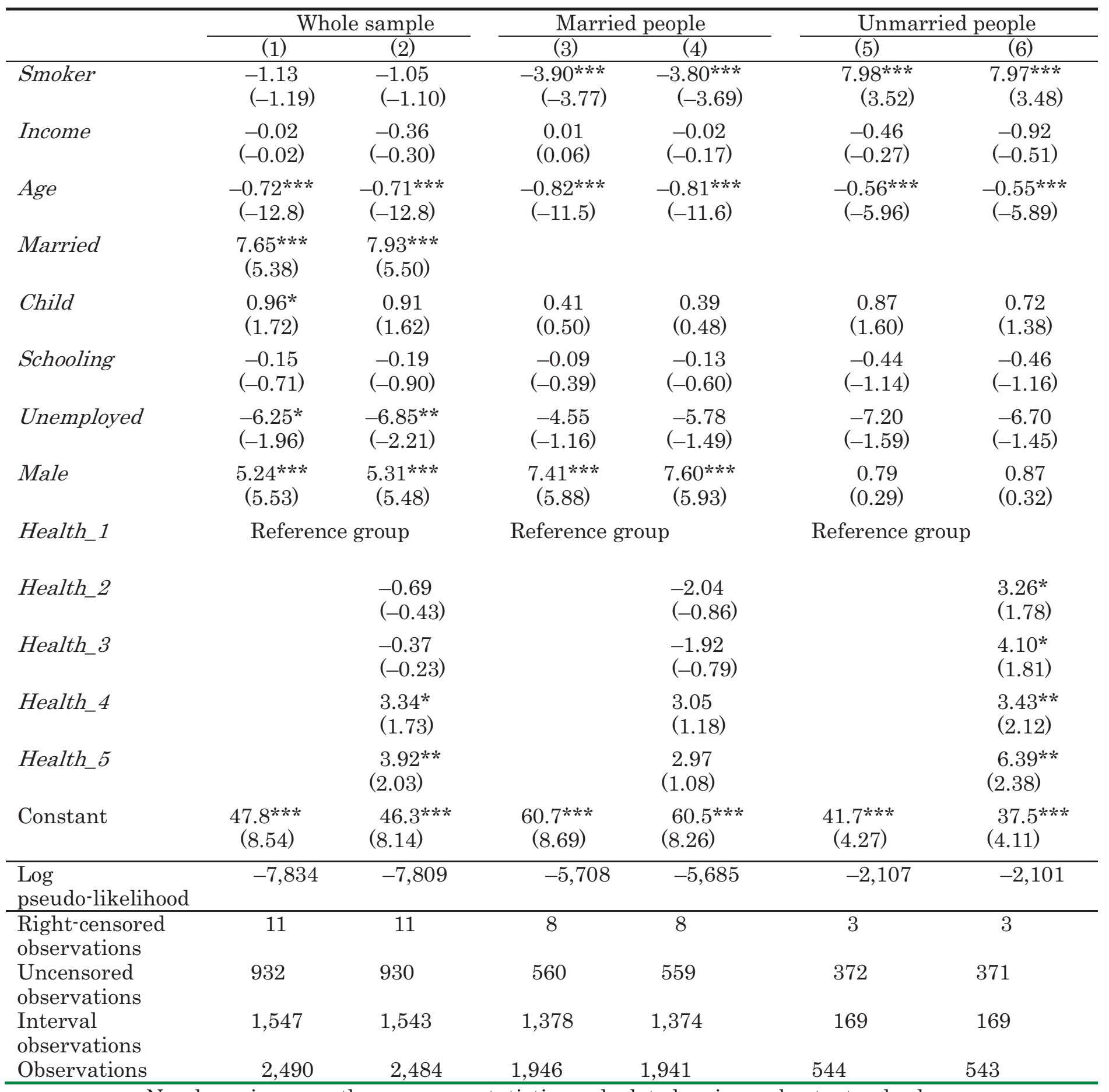

Numbers in parentheses are z-statistics calculated using robust standard errors clustered in the prefecture. * **, and *** indicate significance at the $10 \%, 5 \%$, and $1 \%$ levels, respectively. In all estimations, year dummies were included as independent variables, but they are not reported because of space limitations. 
Table 7 Regression estimation where the dependent variable is Frequency of sex (interval model): Examining the effect of spouse's gender for married couples

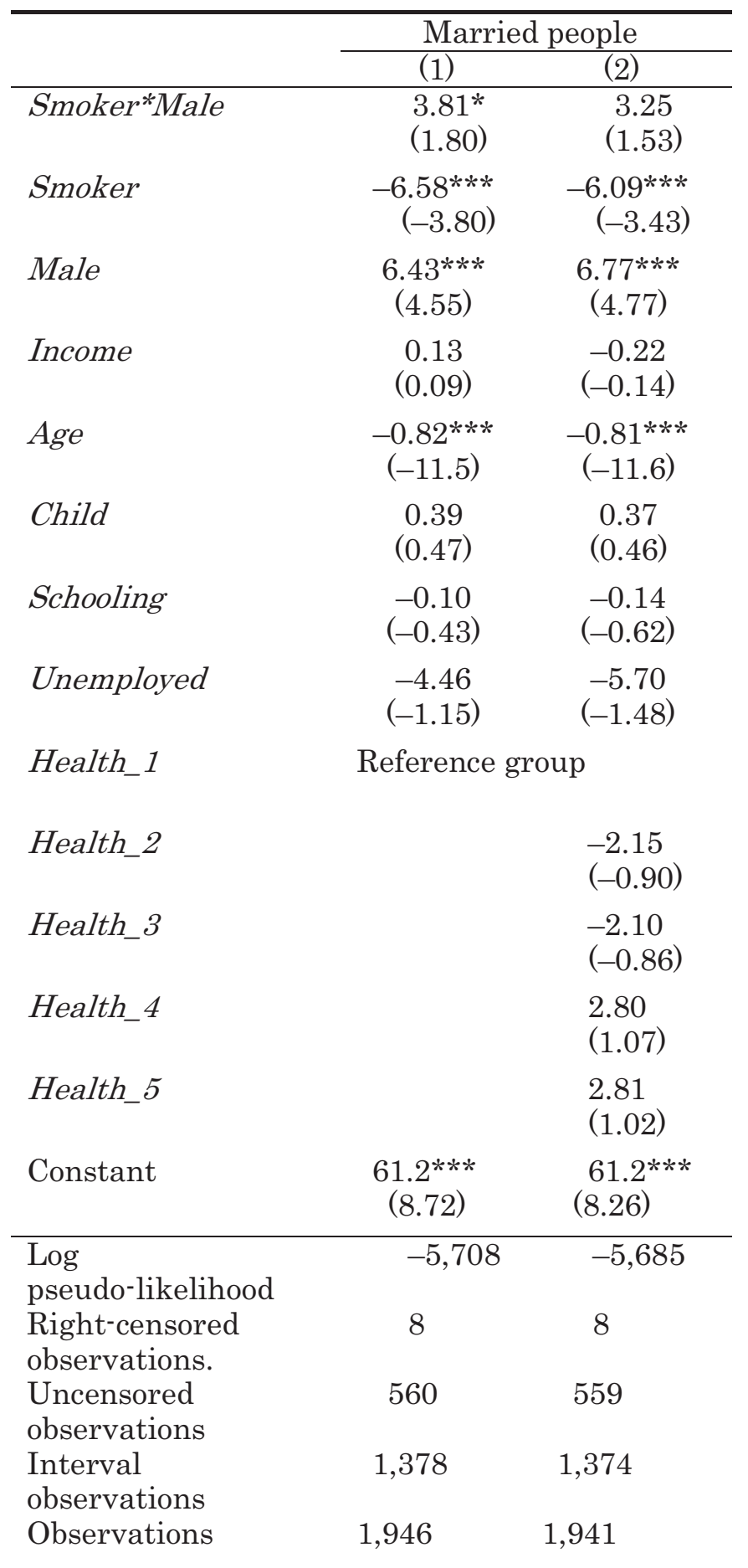

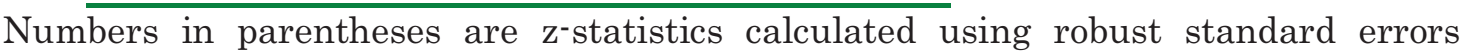
clustered in the prefecture. ${ }^{*}, * *$, and $* * *$ indicate significance at the $10 \%, 5 \%$, and $1 \%$ levels, respectively. In all estimations, year dummies were included as independent variables, but they are not reported because of space limitations. 
Table 8 Regression estimation where the dependent variable is Frequency of sex (interval model): Male sample

\begin{tabular}{lcc}
\hline & $(3)$ & $(4)$ \\
\hline Wife's age & 0.06 & 0.03 \\
*Smoker & $(0.51)$ & $(0.32)$ \\
Wife's age & $-0.58^{* * *}$ & $-0.59^{* * *}$ \\
& $(-2.63)$ & $(-2.68)$ \\
Smoker & -6.22 & -4.98 \\
& $(-0.88)$ & $(-0.74)$ \\
Income & 0.47 & 0.09 \\
& $(0.21)$ & $(0.04)$ \\
Age & -0.34 & -0.32 \\
& $(-1.61)$ & $(-1.55)$ \\
Child & -0.83 & -0.76 \\
& $(-0.65)$ & $(-0.61)$ \\
Schooling & -0.41 & -0.46 \\
& $(-1.33)$ & $(-1.50)$ \\
Unemployed & $-8.75^{* *}$ & $-10.7^{* *}$ \\
& $(-2.11)$ & $(-2.49)$ \\
Health_1 & & \\
Health_2 & & \\
Reference group & & -2.64 \\
Health_3 & & $(-0.60)$ \\
Health_4 & & -4.70 \\
Health_5 & & $(-1.12)$ \\
Constant & & 2.71 \\
Log & & $(0.69)$ \\
pseudo-likelihood & & 0.71 \\
observations. & & $(0.16)$ \\
Uncensored & & $79.5^{* * *}$ \\
observations & & $(6.86)$ \\
Interval & & -3170 \\
Observations & & \\
\hline
\end{tabular}

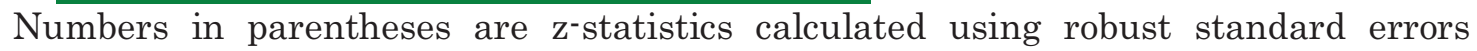
clustered in the prefecture. ***, and *** indicate significance at the $10 \%, 5 \%$, and $1 \%$ levels, respectively. In all estimations, year dummies were included as independent variables, but they are not reported because of space limitations. 
Table 9 Regression estimation where the dependent variable is Frequency of sex (interval model): Female sample

\begin{tabular}{|c|c|c|}
\hline & $(3)$ & (4) \\
\hline $\begin{array}{l}\text { Husband's age } \\
\text { *Smoker }\end{array}$ & $\begin{array}{l}0.15 \\
(1.06)\end{array}$ & $\begin{array}{l}0.14 \\
(1.07)\end{array}$ \\
\hline Husband's age & $\begin{array}{l}-0.20 \\
(-0.82)\end{array}$ & $\begin{array}{l}-0.27 \\
(-1.13)\end{array}$ \\
\hline Smoker & $\begin{array}{l}-13.8 \\
(-1.63)\end{array}$ & $\begin{array}{l}-13.2 \\
(-1.61)\end{array}$ \\
\hline Income & $\begin{array}{c}0.16 \\
(0.08)\end{array}$ & $\begin{array}{l}-0.36 \\
(-0.17)\end{array}$ \\
\hline Age & $\begin{array}{l}-0.56^{* *} \\
(-2.48)\end{array}$ & $\begin{array}{l}-0.48^{* *} \\
(-2.13)\end{array}$ \\
\hline Child & $\begin{array}{l}1.99 * * \\
(2.33)\end{array}$ & $\begin{array}{l}1.98^{* *} \\
(2.26)\end{array}$ \\
\hline Schooling & $\begin{array}{c}0.23 \\
(0.88)\end{array}$ & $\begin{array}{c}0.20 \\
(0.83)\end{array}$ \\
\hline Unemployed & $\begin{array}{c}8.47 \\
(1.05)\end{array}$ & $\begin{array}{c}7.41 \\
(0.99)\end{array}$ \\
\hline \multicolumn{3}{|c|}{ Reference group } \\
\hline Health_2 & & $\begin{array}{l}-1.92 \\
(-0.84)\end{array}$ \\
\hline Health_3 & & $\begin{array}{l}1.13 \\
(0.56)\end{array}$ \\
\hline Health_4 & & $\begin{array}{l}2.89 \\
(1.25)\end{array}$ \\
\hline Health_5 & & $\begin{array}{l}5.07^{* *} \\
(2.34)\end{array}$ \\
\hline Constant & $\begin{array}{l}52.5^{* * *} \\
(6.02)\end{array}$ & $\begin{array}{l}50.3^{* * *} \\
(5.65)\end{array}$ \\
\hline $\begin{array}{l}\text { Log } \\
\text { pseudo-likelihood }\end{array}$ & $-2,478$ & $-2,464$ \\
\hline $\begin{array}{l}\text { Right-censored } \\
\text { observations }\end{array}$ & 1 & 1 \\
\hline $\begin{array}{l}\text { Uncensored } \\
\text { observations }\end{array}$ & 294 & 293 \\
\hline $\begin{array}{l}\text { Interval } \\
\text { observations }\end{array}$ & 558 & 557 \\
\hline Observations & 853 & 851 \\
\hline
\end{tabular}

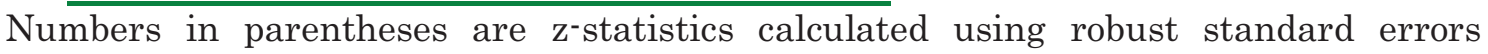
clustered in the prefecture. ***, and *** indicate significance at the $10 \%, 5 \%$, and $1 \%$ levels, respectively. In all estimations, year dummies were included as independent variables, but they are not reported because of space limitations. 